TITLE:

\title{
An N-glycan structure correlates with pulmonary metastatic ability of cancer cells(Abstract_要旨 )
}

\author{
AUTHOR(S): \\ Sakuma, Keiichiro
}

\section{CITATION:}

Sakuma, Keiichiro. An N-glycan structure correlates with pulmonary metastatic ability of cancer cells. 京都大学, 2006, 博士(医学)

ISSUE DATE:

2006-03-23

URL:

http://hdl.handle.net/2433/143872

RIGHT: 


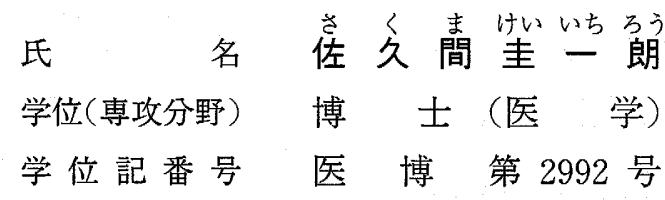

学位授与の日付平 成 18 年 3 月 23 日

学位授与の要件 学 位 規 則 第 4 条第 1 項 該 当

研究科・專攻医学研 究科 内科系専攻

学位論文題目 An $N$-glycan structure correlates with pulmonary metastatic ability of cancer cells

（癌細胞の肺転移能と関連する $N$-結合型糖鎖構造）

論文調查委員 教授藤田潤教授野田亮教授武藤誠

\section{論 文 内 容 の 要 旨}

細胞表面の糖タンパク質糖鎖は癌転移において重要な役割を持つ。高分岐型糖鎖構造やシアリルルイス $-\mathrm{X},-\mathrm{A}$ 構造な どは癌転移を促進する。一方, 癌転移には臟器選択性があることが知られている。臓器選択性を決定する大きな要因の一つ は癌細胞と臓器細胞の親和性であり，おのおのの細胞表面分子の特徵によって決定される。糖鎖は細胞表面に存在し，細胞 間相互作用に扔いて重要な役割を果たす。特に $N$-結合型糖鎖は最表層に存在するため，細胞間相互作用に最初に関与する 分子である。しかし，手法的困難さから $N$-結合型糖鎖の構造パターンはこれまでほとんど解析されてこなかった。1mgの アセトン沈殿検体から $N$-結合型糖鎖構造パターンを決定できる 2 次元 HPLC 解析系を独自に確立し，ヒトやマウスの正 常臓器の糖鎖構造解析を行ったところ，おのおのの臓器は特徵的な糖鎖パターンを示し，個体間の差がほとんど存在しない ことを発見した。また，A2G2F と呼ばれる糖鎖構造がヒト及び C57BL/6 マウスの正常肺において非常に多く存在する糖 鎖であることを特定した。A2G2F は肺においては全 $N$-結合型糖鎖の15\%以上を占めるが，他の臟器では $5 \%$ 以下であり， 特に脳においては $1 \%$ しか認めなかった。A2G2F を合成する際に必要な $\alpha 1,6$-フコース構造を付加する反応は $\alpha-1,6-7$ コシルトランスフェラーゼによって触媒されるが, この酵素遺伝子をノックアウトしたマウスは肺に気腫性変化を示すこと が最近報告された。これらは， $\mathrm{A} 2 \mathrm{G} 2 \mathrm{~F}$ 構造が肺において非常に重要な役割を果たすことを示唆している。この研究では, $\mathrm{A} 2 \mathrm{G} 2 \mathrm{~F}$ 構造を多く持つ癌細胞と少ない癌細胞の間で肺転移能に差があるかを検証した。

Lens culinaris agglutinin（LCA）は $\alpha 1,6$-フコース構造を認識するレクチンである。同一原発巣から肺と肝臓に転移し たヒト剖検検体を LCA で染色し，染色強度を定量比較したところ，肺転移部位の癌細胞は肝転移部位の癌細胞よりも特に 細胞膜が有意に強く染色された。C57BL/6 マウスの尾静脈および脾臓から B16メラノーマ細胞を注入し， 3 週間後に肺転 移および肝転移を摘出して $N$-結合型糖鎖構造パターンを解析したところ，肺転移では有意に多くの A2G2F 構造を認めた。 同時に切片を作成し，正常肺細胞の混入による結果ではないことを確認した。さらにB16 培養細胞から，細胞表面の $\mathrm{A} 2 \mathrm{G} 2 \mathrm{~F}$ 構造がより多い細胞集団とより少ない細胞集団をLCA を用いてフローサイトメーターで分離して培養し, それぞ れを C57BL/6 マウスの尾静脈から注入したところ, 前者は有意に多くの肺転移結節を形成した。以上の結果から, 癌細胞 表面に存在する A2G2F 構造は肺転移能に大きく関与する可能性が示唆された。今回の研究結果は臨床的にも癌患者の肺転 移リスクを事前評価できる可能性を示唆しており意義が大きい。

\section{論 文審 査の 結 果の 要旨}

細胞表面の糖タンパク質糖鎖は癌転移において重要な役割を果たすが，癌転移の臟器選択性と $N$-結合型糖鎖の関係につ いての研究は少ない。ヒト及びマウスの正常肺には A2G2F と呼ばれる， $\alpha 1,6-$ フコースを持つ糖鎖構造が他の臓器に比べ て非常に多く存在する。この研究では癌細胞表面の A2G2F 構造が肺転移能に関連するかを検証した。同一原発巣から肺と 肝臓に転移したヒト剖検検体を， $\alpha 1,6$-フコースを認識するレクチンである Lens culinaris agglutinin (LCA) で染色した 
ところ, 肺転移では肝転移よりも転移癌細胞の細胞膜が有意に強く染色された。C $57 \mathrm{BL} / 6$ マウスの尾静脈抢よび脾臓から B16 メラノーマ細胞を注射し，肺および肝転移結節を摘出して $N$-結合型糖鎖構造パターンを解析したところ，肺転移では 有意に多くの $\mathrm{A} 2 \mathrm{G} 2 \mathrm{~F}$ 構造を認めた。さらに B16 培養細胞から, 細胞表面の $\mathrm{A} 2 \mathrm{G} 2 \mathrm{~F}$ 構造が多い細胞集団と少ない細胞集団 をLCAを用いてフローサイトメーターで分離して培養し，それぞれをC57BL/6 マウスの尾静脈から注射したところ，前 者は有意に多くの肺転移結節を形成した。以上の結果から, 癌細胞表面に存在する $\mathrm{A} 2 \mathrm{G} 2 \mathrm{~F}$ 構造は肺転移能に大きく関与す る可能性が示唆された。今回の研究結果は癌患者の肺転移リスクを事前評価できる可能性を示唆しており, 臨床的にも意義 が大きい。

したがって，本論文は博士 (医学) の学位論文として価值あるものと認める。

なお，本学位授与申請者は，平成18年 1 月 30 日実施の論文内容とそれに関連した試問を受け，合格とみとめられたもので ある。 